\title{
PEMBERIAN PUPUK KANDANG SEBAGAI PEMBENAH TANAH UNTUK PERTUMBUHAN DAN HASIL MELON (Cucumis melo L.) DI ULTISOL
}

\author{
Eka Nurjanah ${ }^{1}$, Sumardi $^{1 *}$, Prasetyo $^{1}$ \\ ${ }^{1}$ Program Studi Agroekoteknologi, Fakultas Pertanian Universitas Bengkulu \\ * Corresponding Author: sumardi@unib.ac.id
}

\begin{abstract}
[MANURE APPLICATION AS A SOIL AMENDMENT TO PROMOTE GROWTH AND YIELD OF MELON (Cucumis melo L.) IN ULTISOL]. The application of manure may overcome soil fertility problems in Ultisol triggered by low $\mathrm{pH}$, high $\mathrm{P}$ retention, high content of $\mathrm{Al}$ and $\mathrm{Fe}$, and low CEC. The objective of this study was to determine the optimum dose of different manures applied to promote the best growth and yield of melon. The study was conducted from February to May 2019 at the Experimental Plot of the Faculty of Agriculture, University of Bengkulu. Three different manures (chicken, cow, and goat manure) were applied at 5, 10, 15, and 20 tons/ha. These treatments were arranged in Completely Randomized Design with three replications. The results show that the enhancement in chlorophyll content (SPAD index) was highest in plots solely applied with 20 tons $\mathrm{ha}^{-1}$ manure, whereas the application of manure even at 20 tons/ha had no effects on melon yield and its components. Manure types solely promoted plant height, maturity date, fruit diameter, and soluble solids content (Brix). Melon growth and yield were not affected by the combined application of manure type and dose. These indicate that the application of manure types irrespective of the amount applied failed to solve fertility problems in Ultisol where the melon was grown.
\end{abstract}

Keyword: soil amendment, manure type, manure dose, Ultisol, melon

\begin{abstract}
ABSTRAK
Aplikasi pupuk kandang dapat mengatasi masalah kesuburan tanah di Ultisol yang dipicu oleh $\mathrm{pH}$ rendah, retensi $\mathrm{P}$ yang tinggi, kandungan $\mathrm{Al}$ dan Fe yang tinggi, dan KTK rendah. Tujuan penelitian ini untuk menentukan dosis optimal berbagai pupuk kandang yang diberikan untuk mendapatkan pertumbuhan dan hasil melon yang terbaik. Penelitian dilakukan dari Februari hingga Mei 2019 di Plot Percobaan Fakultas Pertanian, Universitas Bengkulu. Tiga pupuk kandang yang berbeda (ayam, sapi, dan kotoran kambing) diaplikasikan pada 5, 10, 15, dan 20 ton/ha. Perlakuan ini diatur dalam Rancangan Acak Lengkap dengan tiga ulangan. Hasil penelitian menunjukkan bahwa peningkatan kandungan klorofil (SPAD indeks) tertinggi di petak percobaan yang diberi pupuk kandang 20 ton/ ha, sedangkan perlakuan ini tidak meningkatkan hasil melon dan komponennya. Jenis pupuk kandang hanya meningkatkan tinggi tanaman, umur panen, diameter buah, dan kandungan padatan terlarut (Brix). Aplikasi kombinasi jenis dan dosis pupuk kandang tidak meningkatkan pertumbuhan dan hasil melon. Hal ini menunjukkan bahwa aplikasi jenis pupuk kandang terlepas dari jumlah yang diberikan gagal untuk menyelesaikan masalah kesuburan tanah di Ultisol dimana melon ditanam.
\end{abstract}

Kata kunci: amandemen tanah, dosis pupuk kandang, jenis pupuk kandang, melon, Ultisol 


\section{PENDAHULUAN}

Buah melon (Cucumis melo L.) merupakan salah satu komoditi buah-buahan semusim yang digemari oleh masyarakat karena mempunyai keunggulan pada rasanya yang manis, tekstur daging yang renyah, warna daging yang bervariasi, mempunyai aroma yang khas, dan kaya vitamin A dan C (Karya, 2009). Berdasarkan data Badan Pusat Statistik tahun 2017, produksi melon di Indonesia mengalami penurunan. Produksi melon pada tahun 2014 mencapai 150.356 ton, sedangkan pada tahun 2015 dan 2016 produksi menjadi 137.887 ton dan 117.344 ton. Produksi buah melon untuk Provinsi Bengkulu sendiri terjadi fluktuasi produksi melon yang cukup signifikan. Pada tahun 2014 produksi mencapai 142 ton, pada tahun 2015 produksi melon menurun drastis menjadi 40 ton namun pada tahun 2016 produksi buah melon meningkat pesat enam kali lipat dibandingkan tahun sebelumnya hingga mencapai 240 ton (Badan Pusat Statistik, 2017).

Ultisol merupakan jenis tanah yang sangat luas sebarannya yaitu 45.794 .000 ha atau sekitar $25 \%$ dari total luas daratan Indonesia (Subagyo et al., 2004). Tanah ini rendah kandungan bahan organik dan hara terutama $\mathrm{P}$ serta kation-kation dapat ditukar seperti $\mathrm{Ca}, \mathrm{Mg}, \mathrm{Na}$, dan $\mathrm{K}$, kadar Al tinggi, kapasitas tukar kation rendah, dan peka terhadap erosi. Salah satu upaya untuk meningkatkan produktivitas tanah ultisol dengan pemberian pupuk organik maupun pupuk anorganik yang cukup agar pertumbuhan dan produksi dapat meningkat. Penggunaan pupuk anorganik yang berdosis tinggi dalam kurun waktu yang panjang menyebabkan terjadinya kemerosotan kesuburan tanah karena tanah mengalami kekurangan hara dan semakin merosotnya kandungan bahan organik. Untuk mengatasi masalah ini salah satu solusi yang dapat dilakukan ialah penggunaan pupuk organik sebagai pengganti pupuk kimia yang ramah lingkingan dan tidak mencemari alam (Mariana et al., 2012).

Prihmantoro (2007) menyatakan bahwa peningkatkan hasil tanaman dapat dipengaruhi oleh banyak faktor salah satunya adalah dosis peupuk dan waktu pemberiannya. Dalam pelaksanaan pertanian organik, peran bahan organik sangatlah penting karena menjadi sumber energi bagi organisme, menambah kesuburan tanah dan dapat membentuk agregat tanah yang stabil (Badan Pusat Statistik, 2007). Pupuk kandang dapat berfungsi sebagai energi bagi mikroorganisme, penyedia sumber hara, penambah kemampuan tanah menahan air dalam tanah dan untuk memperbaiki struktur tanah (Setiawan, 2010)..

Pupuk kandang merupakan bahan organik yang telah mengalami dekomposisi dan dapat digunakan sebagai pupuk organik (Sutanto, 2002). Setiap pupuk kandang mempunyai kandungan unsur hara yang berbeda-beda, karena masing-masing ternak mempunyai sifat khas tersendiri yang ditentukan oleh jenis pakan dan umur ternak tersebut.
Pupuk kandang ayam mengandung beberapa unsur hara makro yang sangat dibutuhkan oleh tanaman seperti nitrogen $(\mathrm{N})$, phosfor $(\mathrm{P})$, kalium (K) dan beberapa unsur hara mikro seperti mangan $(\mathrm{Mn})$, kalsium $(\mathrm{Ca})$, besi $(\mathrm{Fe})$ dan beberapa unsur hara yang lain yang dapat membantu dalam produksi tanaman (Andayani \& La Sarido, 2013 ; Mohamed et al., 2010). Pupuk kotoran sapi sifatnya lebih baik dari pada pupuk alam lainnya maupun pupuk buatan, karena merupakan humus yang mengandung senyawa-senyawa organik dan merupakan sumber unsur hara makro yang penting bagi pertumbuhan dan perkembangan tanaman (Mayun, 2007). Pupuk kandang kambing mempunyai sifat memperbaiki aerasi tanah, menambah kemampuan tanah menahan unsur hara, meningkatkan kapasitas menahan air, meningkatkan daya sangga tanah, sumber energi bagi mikroorganisme tanah dan sebagai sumber unsur hara. Pupuk kandang kambing mengandung unsur $\mathrm{N}$ yang dapat mendorong pertumbuhan organ - organ yang berkaitan dengan fotosintesis yaitu daun. (Subhan et al., 2005; Rizwan, 2008).

Hasil penelitian Purnomo et al. (2013) menunjukkan bahwa perlakuan pupuk kandang 20 ton/ha menghasilkan diameter batang mentimun yang besar. Aplikasi kompos kotoran ayam pada dosis 15 ton/ha berpengaruh sangat nyata terhadap total produksi buah tanaman mentimun (Tufaila, 2014). Dosis pupuk kandang ayam 20 ton/ha menghasilkan pertumbuhan tanaman pakchoy yang terbaik dibandingkan dosis yang lebih rendah (Sari et al., 2016).

Penelitian ini bertujuan untuk menjelaskan interaksi antara jenis pupuk kandang dengan dosis pupuk kandang terhadap pertumbuhan dan hasil tanaman melon serta dosis optimum pupuk kandang yang dapat memberikan pertumbuhan dan hasil tanaman melon terbaik.

\section{METODE PENELITIAN}

Penelitian telah dilaksanakan pada bulan Februari - Mei 2019 bertempat di Kebun Percobaan Fakultas Pertanian UNIB Medan Baru, Kota Bengkulu. Adapun bahan-bahan yang digunakan dalam penelitan ini adalah benih melon varietas Madesta, air, tanah top soil, pupuk kandang ayam, pupuk kandang sapi, pupuk kandang kambing dan polibag. Sedangkan alat digunakan adalah cangkul, meteran, bilahan bambu, timbangan, selang air, tali rapia, alat tulis, penggaris, map label, gunting, SPAD meter, refraktometer, penetrometer dan gelas ukur.

Disain yang digunakan dalam penelitian ini ialah percobaan faktorial 2 faktor dengan Rancangan Acak Lengkap (RAL). Faktor pertama adalah jenis pupuk yang terdiri atas tiga macam yaitu kotoran ayam, kotoran sapi, dan kotoran kambing. Faktor kedua yaitu dosis pemupukan yang terdiri atas empat taraf 
yaitu 5 ton/ha, 10 ton/ha, 15 ton/ha, dan 20 ton/ha. Percobaan diulang sebanyak 3 kali dan masing-masing kombinasi perlakuan terdapat tiga sampel tanaman. Data yang dikumpulkan dianalisis secara statistik dengan analisis varians pada taraf $5 \%$. Untuk mendapatkan jenis pupuk kandang yang menghasilkan pertumbuhan dan hasil melon yang terbaik digunakan uji Beda Nyata Terkecil (BNT). Untuk mendapatkan dosis pupuk kandang yang optimum terhadapat pertumbuhan dan hasil melon digunakan metode polinomial orthogonal.

\section{HASIL DAN PEMBAHASAN}

Hasil analisis varian menunjukkan bahwa terdapat interaksi yang tidak nyata $(\mathrm{P}>0,05)$ antara jenis pupuk kandang dan dosis pupuk kandang yang diberikan. Hal ini berarti bahwa antara jenis pupuk kandang (ayam, sapi dan kambing) memberikan respon pertumbuhan dan hasil melon yang sama terhadap beberapa dosis pupuk kandang yang diberikan, begitu juga dengan dosis pupuk kandang.

Tabel 1. Rata-rata pertumbuhan tanaman melon pada tiga jenis pupuk kandang di Ultisol

\begin{tabular}{l|c|c|c|c|}
\hline $\begin{array}{l}\text { Jenis Pupuk } \\
\text { Kandang }\end{array}$ & $\begin{array}{c}\text { Tinggi } \\
\text { Tanaman } \\
(\mathrm{cm})\end{array}$ & $\begin{array}{c}\text { Kehijauan } \\
\text { Daun }\end{array}$ & $\begin{array}{c}\text { Umur Bunga } \\
\text { Jantan (hst) }\end{array}$ & $\begin{array}{c}\text { Umur Bunga } \\
\text { Hermaprodit } \\
\text { (hst) }\end{array}$ \\
\hline Ayam & $189,11 \mathrm{a}$ & 36,18 & $26,05 \mathrm{a}$ & 34,87 \\
\hline Sapi & $175,68 \mathrm{ab}$ & 37 & $25,87 \mathrm{a}$ & 34,59 \\
\hline Kambing & $169,99 \mathrm{~b}$ & 35,24 & $25,33 \mathrm{~b}$ & 34,72 \\
\hline Keterangan : Angka-angka yang diikuti oleh huruf yang berbeda pada \\
\hline \multicolumn{4}{l}{ kolom yang sama, berbeda nyata pada BNT 5\% } \\
\hline
\end{tabular}

Jenis pupuk kandang ayam nyata pengaruhnya $(\mathrm{P} \leq 0,05)$ terhadap tinggi tanaman dan umur bunga jantan. Rata-rata tinggi tanaman tertinggi $189,11 \mathrm{~cm}$ dan umur bunga jantan terbesar rata-rata 26,05 hst dihasilkan oleh pupuk kandang ayam (Tabel 1). Hasil penelitian Safei et al. (2014) dan Laude \& Tambing (2010) menunjukkan perilaku yang sama yaitu pupuk kandang ayam memacu peningkatan tinggi tanaman yang berbeda nyata pada 2-6 mst, dibandingkan tanaman yang tidak diberikan pupuk kandang ayam. Demikian pula hasil penelitian Azalika et al. (2018) yang menunjukkan bahwa pupuk kandang ayam mampu memberikan hasil padi yang tertinggi. Kandungan $\mathrm{N}$ yang tinggi pada pupuk kandang ayam lebih cepat diserap oleh tanaman dibandingkan pupuk kandang kambing dan pupuk kandang sapi. Selain itu, di dalam pupuk kandang ayam tersebut tercampur sisa-sisa makanan ayam yang akan berpengaruh terhadap penambahan unsur hara kedalam pupuk kandang ayam terhadap tanaman (Isnaini, 2006).

Tingkat kehijauan daun menunjukkan ada perbedaan yang tidak nyata antara jenis pupuk kandang ayam, kambing dan sapi. Pupuk kandang kambing mengandung $\mathrm{N}$ dan $\mathrm{K}$ lebih tinggi dibandingkan dengan kotoran sapi. Unsur K sendiri sangat berperan penting dalam hal metabolisme pada bagian tubuh tanaman seperti halnya pada pembelahan sel dan proses sintesis protein, serta berperan penting dalam pembentukan buah bagi tanaman (Silvia et al., 2012).

Pupuk kandang ayam memliki kandungan $\mathrm{N}$ yang cukup tinggi sehingga $\mathrm{N}$ lebih cepat diserap oleh tanaman dibandingkan dengan pupuk kandang kambing dan pupuk kandang sapi. Pupuk kandang sapi banyak mengandung hara yang dibutuhkan tanaman seperti $\mathrm{N}, \mathrm{P}, \mathrm{K}, \mathrm{Cl}$, serta unsur-unsur lainnya. Unsur $\mathrm{N}$ juga dibutuhkan tanaman dalam jumlah yang banyak pada setiap tahap pertumbuhan tanaman, khususnya pada tahap pertumbuhan vegetatif, seperti perkembangan batang dan daun. Unsur hara $\mathrm{N}$ pada pupuk dapat memacu tanaman dalam pembentukan asam-asam amino menjadi protein (Sumpena, 2001).. Protein yang terbentuk digunakan untuk membentuk hormon pertumbuhan, yakni hormon auksin, giberelin dan sitokinin. Giberelin akan meningkatkan kegiatan metabolisme dan laju fotosintesis (Adimihardja et al., 2013). Karbohidrat yang terbentuk juga akan meningkat, selanjutnya pertumbuhan akar, batang dan daun juga akan meningkat dengan demikian tinggi tanaman akan semakin bertambah.

Rata-rata muncul bunga jantan tercepat yaitu pada pupuk kandang ayam dengan rata-rata $26 \mathrm{mst}$, yang berbeda tidak nyata dengan tanaman yang mendapat pupuk kandang sapi. Sedangkan muncul bunga jantan terlama yaitu pada jenis pupuk kandang kambing. Akan tetapi umur bunga hermaprodit pertama muncul berbeda tidak nyata antara jenis pupuk kandang ayam, sapi dan kambing. Pada fase pembungaan terdapat faktor internal dan eksternal yang mempengaruhi. Faktor internal ialah faktor yang berasal dari tanaman misalnya fitohormon dan genetik, sedangkan faktor eksternal berasal dari luar tanaman yaitu faktor lingkungan seperti cahaya, suhu dan unsur hara. Pada tanaman yang monoesis yang hanya mempunyai bunga-bunga berkelamin satu, intensitas cahaya dapat memberikan efek yang berbeda pada inisiasi bunga jantan dan bunga betina. Intensitas cahaya yang tinggi merangsang pembentukan bunga betina, sedangkan intensitas cahaya yang rendah dapat disebabkan oleh naungan lebih merangsang terbentuknya bunga jantan (Sayekti, 2016).

Umur panen buah melon tercepat rata-rata 61 hst dihasilkan oleh tanaman yang diberi jenis pupuk kandang ayam yang berbeda tidak nyata dengan pupuk kandang kambing. Umur panen terlama rata-rata 70 hst dihasilkan oleh tanaman yang diperlakukan jenis pupuk kandang sapi (Tabel 2). Tanaman melon yang diberi jenis pupuk kandang ayam terlebih dahulu dipanen karena dalam masa panen tanaman banyak yang terserang ulat tanah/uret yang menyerang akar tanaman yang dapat menyebabkan tanaman mati. 
Tabel 2. Rata-rata penampilan hasil tanaman melon akibat perlakuan tiga jenis pupuk kandang di Ultisol

\begin{tabular}{l|c|c|c|c|c|c|c|}
\hline $\begin{array}{l}\text { Jenis Pupuk } \\
\text { Kandang }\end{array}$ & $\begin{array}{c}\text { Umur } \\
\text { Panen (hst) }\end{array}$ & $\begin{array}{c}\text { Bobot } \\
\text { Buah } \\
(\mathrm{g} / \mathrm{buah})\end{array}$ & $\begin{array}{c}\text { Diameter } \\
\text { Buah } \\
(\mathrm{cm})\end{array}$ & $\begin{array}{c}\text { Kekerasan } \\
\text { Buah } \\
\left(\mathrm{kgf} / \mathrm{cm}^{2}\right)\end{array}$ & $\begin{array}{c}\text { Tebal } \\
\text { Daging } \\
(\mathrm{cm})\end{array}$ & $\begin{array}{c}\text { Tingkat } \\
\text { Kemanisan } \\
(\% \text { brix })\end{array}$ & $\begin{array}{c}\text { Volume } \\
\text { Akar } \\
\left(\mathrm{cm}^{3}\right)\end{array}$ \\
\hline Ayam & $61,83 \mathrm{~b}$ & 615,14 & $9,42 \mathrm{~b}$ & 2,5 & 2,83 & $6,19 \mathrm{~b}$ & 5,59 \\
\hline Sapi & $70,07 \mathrm{a}$ & 702,5 & $10,84 \mathrm{a}$ & 2,48 & 2,99 & $7,93 \mathrm{a}$ & 6,07 \\
\hline Kambing & $67,19 \mathrm{ab}$ & 788,19 & $11,18 \mathrm{a}$ & 2,67 & 3,03 & $7,65 \mathrm{a}$ & 6,08 \\
\hline Keterangan : Angka-angka yang diikuti oleh huruf yang berbeda pada kolom yang sama berbeda nyata \\
\hline
\end{tabular}

Bobot buah melon berbeda tidak nyata di antara ketiga jenis pupuk kandang yang diteliti. Ketiga jenis pupuk kandang tersebut memberikan hasil bobot buah yang rata-rata seimbang. Perkembangan buah dan pematangan buah perlu didukung hara yang cukup dan seimbang yaitu unsur hara $\mathrm{N}, \mathrm{P}, \mathrm{K}$ dan $\mathrm{Ca}$. Bobot buah tanaman tergantung dari unsur hara yang diperoleh oleh tanaman itu sendiri (Mardianto, 2014).

Diameter buah melon yang dihasilkan berbeda nyata antara tanaman melon yang diberi jenis pupuk kandang ayam dan dua jenis pupuk kandang lainnya. Jenis pupuk kandang ayam menghasilkan diameter buah rata-rata $9 \mathrm{~cm}$, sedangkan pada jenis pupuk kandang sapi dan kambing mencapai rerata 10-11 $\mathrm{cm}$. Diameter buah erat hubungannya dengan bobot buah, Jenis pupuk kandang ayam menghasilkan bobot buah rata-rata $615,14 \mathrm{~g}$ lebih ringan dibandingkan dengan jenis pupuk kandang sapi dan kambing mencapai 702-788 g/buah.

Penyerapan unsur hara fosfor $(\mathrm{P})$ berguna dalam pertumbuhan vegatatif tanaman, seperti pembentukan akar, pembentukan inti sel dan pembelahan sel, merangsang pembungaan, pembentukan biji, serta memperkuat daya tahan tanaman terhadap penyakit. Jumlah akar yang banyak membuat tanaman mampu menyerap air beserta unsur hara lebih banyak dalam proses pembungaan serta produksi buah dan biji (Souri, 2001).

Kekerasan buah melon dalam penelitian ini berbeda tidak nyata antar ketiga jenis pupuk kandang yang diberikan. Curah hujan yang tinggi selama penelitian berpengaruh terhadap kadar air buah melon sehingga menyebabkan tingkat kekerasan antar jenis pupuk kandang tidak nyata pengaruhnya.

Tebal daging buah melon, antar perlakuan ketiga jenis pupuk kandang terdapat perbedaan yang tidak nyata. Buah melon dengan bobot yang tinggi mengandung banyak kandungan air sehingga tebal buahnya rendah dan saling mempengaruhi antar bobot buah dan ketebalan daging. Selain bobot buah, ketebalan daging buah juga dipengaruhi oleh jumlah daun. Gardner et al. (1991) menyatakan bahwa bagian tanaman yang memberikan kontribusi paling banyak terhadap pertumbuhan dan perkembangan tanaman adalah daun dan sebagian asimilasi tetap tertinggal dalam jaringan untuk pemeliharaan sel.

Melon mulai dipanen pada umur 61 hst dengan tujuan agar kualitas melon tetap baik dan tidak mudah rusak sehingga dapat dijual dengan cepat. Namun demikian, pada umur panen yang sama, tidak semua varietas mencapai matang fisiologis sesuai yang diharapkan. Hal tersebut menyebabkan tingkat kemanisan melon relatif rendah. Pada umur panen melon jenis pupuk kandang ayam yaitu 61 hst dan memiliki tingkat kemanisan hanya 6,15\% Brix. Jenis pupuk kandang sapi dan kambing pada umur panen 67-70 hst menghasilkan tingkat kemanisan 7,65-7,93\% Brix yang lebih tinggi dari yang dihasilkan oleh jenis pupuk kandang ayam.

Kualitas buah melon yang didasarkan pada tingkat kemanisannya diukur dengan \% sukrosa atau ${ }^{\circ}$ Brix. Menurut International $\mathrm{Ag}$ Labs Inc., terdapat empat kelas kualitas melon yang didasarkan pada tingkat kemanisan, yaitu : buruk $8 \%$ Brix, sedang 12 $\%$ Brix, baik $14 \%$ Brix dan sangat baik $16 \%$ Brix. Kualitas melon yang dihasilkan dari penelitian hanya mencapai rerata $7 \%$ Brix tergolong ke kriteria buruk. Melon yang dihasilkan memiliki tingkat kemanisan melon yang lebih rendah dari seharusnya. Pada kondisi ini, tanaman melon sempat mengalami kekurangan intensitas cahaya matahari akibat hujan deras pada proses pematangan buah sehingga kadar air pada buah tinggi. Salah satu kriteria buah dengan kualitas baik dan disukai konsumen ialah mempunyai kekerasan tinggi dengan kadar air sedang (Deus et al., 2014). Buah yang memiliki kadar air lebih dari 95\% akan mudah busuk bila disimpan sehingga mudah pecah dan terasa lembek apabila dikonsumsi. Sesuai dengan hasil korelasi 
antara derajat kemanisan dan tebal daging buah membuktikan bahwa semakin tebal daging buah maka tingkat kemanisan akan semakin tinggi. Apabila daging buah semakin tebal maka kadar air juga akan semakin menurun sehingga derajat kemanisan akan semakin meningkat.

Perbedaan kadar gula buah melon diduga karena pengaruh faktor lingkungan yaitu intensitas cahaya matahari (Affandi, 2008). Cahaya matahari sangat berpengaruh terhadap proses fotosintesis yaitu mempengaruhi proses perombakan karbohidrat di dalam tanaman. Semakin tinggi intensitas cahaya matahari, proses fotosintesis semakin meningkat sehingga perombakan karbohidrat juga meningkat yang mempengaruhi kandungan kadar gula buah.

Pada peubah volume akar terdapat perbedaan yang tidak nyata antara ketiga jenis pupuk kandang yang diuji. Unsur hara yang diserap oleh akar berasal dari bahan organik pupuk kandang (ayam, kambing dan sapi), seperti yang diketahui bahwa pupuk organik memiliki kandungan unsur hara yang baik untuk tanaman. Volume akar merupakan selisih dari volume air yang naik setelah akar dimasukkan ke gelas ukur dengan volume air sebelumnya.

Pemberian bahan organik pada tanaman melon memberikan hasil dan kualitas yang lebih baik jika dibandingkan dengan hasil yang diperoleh pada pemberian pupuk kimia (Safuan \& Bahrun, 2012). Hal ini disebabkan karena bahan organik selain memberikan unsur hara makro pupuk ini juga mengandung unsur hara mikro yang dibutuhkan oleh tanaman melon. Rosmarkam \& Yuwono (2002) menyatakan bahwa bahan organik dalam proses mineralisasi melepaskan unsur hara yang dibutuhkan tanaman yang lengkap.

Dosis pupuk kandang mampu meningkatkan tingkat kehijauan daun yang membentuk hubungan linear dengan persamaan regresi $\hat{y}=31,1+0,403 x$ dengan koefisien determinasi $r^{2}=0,4737$. Hal ini berarti pada setiap penambahan satu satuan dosis pupuk kandang akan diikuti dengan peningkatan 0,403 satuan tingkat kehijauan daun. Tingkat kehijauan daun dapat meningkat seiring dengan pemberian dosis pupuk kandang hingga 20 ton/ha (Gambar 1).

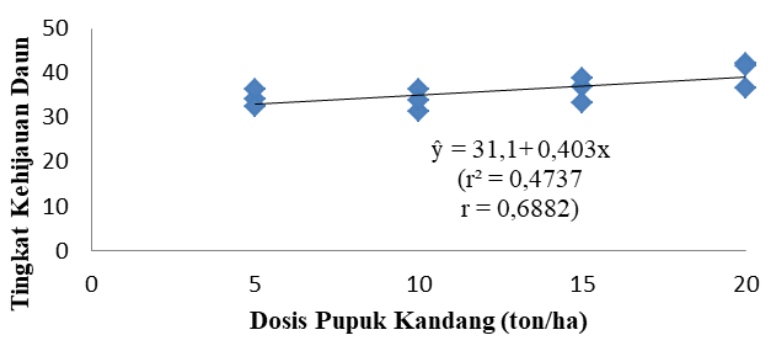

Gambar 1. Kurva hubungan antara dosis pupuk kandang dan tingkat kehijauan daun
Pada peubah tinggi tanaman, umur bunga jantan dan umur bunga betina terdapat perbedaan yang tidak nyata antar penambahan dosis pupuk kandang yang diberikan. Akan tetapi dengan pemberian perlakuan menggunakan pupuk organik secara rata-rata menghasilkan pertumbuhan dan hasil yang lebih baik dibandingkan menggunakan pupuk anorganik.

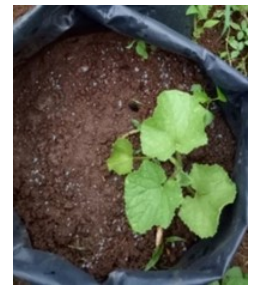

(a)
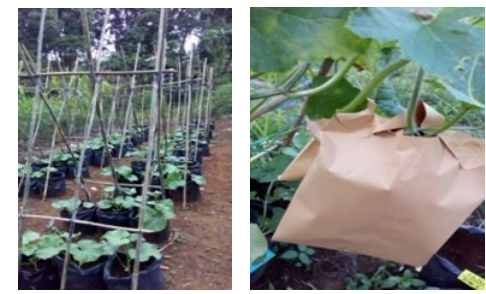

(b)
Gambar 2 a. Kontrol, b. Pertumbuhan tanaman dengan perlakuan jenis dan dosis pupuk kandang

Umur bunga jantan dan bunga hermaprodit terdapat perbedaan yang tidak nyata dengan peningkatan dosis pupuk kandang yang diberikan. Pembungaan merupakan masa transisi dari fase vegetatif menuju fase generatif yang ditandai dengan munculnya kuncup-kuncup bunga. Ketersediaan unsur P dan K pada fase ini sangat berperan. Fungsi dari $\mathrm{P}$ dalam tanaman adalah untuk merangsang pertumbuhan akar, khususnya akar tanaman muda, mempercepat serta memperkuat pertumbuhan tanaman muda menjadi tanaman dewasa, membantu asimilasi dan pernafasan sekaligus mempercepat pembungaan dan menaikkan persentase bunga menjadi buah (Setyawaty, 2012).

Pada fase pembungaan terdapat faktor internal dan eksternal yang mempengaruhi. Faktor internal ialah faktor yang berasal dari tanaman misalnya fitohormon dan genetik, sedangkan faktor eksternal berasal dari luar tanaman yaitu faktor lingkungan seperti cahaya, kelembaban, intensitas cahaya, suhu dan unsur hara. Pada tanaman yang monoesis yang hanya mempunyai bunga-bunga berkelamin satu, intensitas cahaya dapat memberikan efek yang berbeda pada inisiasi bunga jantan dan bunga betina. Intensitas cahaya yang tinggi merangsang pembentukan bunga betina, sedangkan intensitas cahaya yang rendah yang dapat disebabkan oleh naungan lebih merangsang terbentuknya bunga jantan (Sitompul \& Guritno, 1995).

Secara rata-rata umur panen, bobot buah, diameter buah, kekerasan buah, tebal daging, tingkat kemanisan dan volume akar tanaman melon seperti terlihat pada Tabel 3.. Peningkatan dosis pupuk kandang yang diberikan memberikan pengaruh yang tidak nyata terhadap variabel hasil. Pemberian pupuk organik dapat meningkatkan pertumbuhan tanaman, klorofil, karbohidrat dan protein dibandingkan dengan pupuk anorganik (Patil, 2010). 
NURJANAH et al.

Tabel 3. Hasil tanaman melon pada empat dosis pupuk kandang

\begin{tabular}{|c|c|c|c|c|c|c|c|}
\hline $\begin{array}{c}\text { Dosis Pupuk } \\
\text { Kandang } \\
\text { (ton/ha) }\end{array}$ & $\begin{array}{l}\text { Umur } \\
\text { Panen } \\
\text { (hst) }\end{array}$ & $\begin{array}{c}\text { Bobot } \\
\text { Buah } \\
\text { (g/buah) }\end{array}$ & $\begin{array}{c}\text { Diameter } \\
\text { Buah } \\
(\mathrm{cm})\end{array}$ & $\begin{array}{c}\text { Kekerasan } \\
\text { Buah } \\
\left(\mathrm{kgf} / \mathrm{cm}^{2}\right) \\
\end{array}$ & $\begin{array}{c}\text { Tebal } \\
\text { Daging } \\
(\mathrm{cm})\end{array}$ & $\begin{array}{l}\text { Tingkat } \\
\text { Kemanisan } \\
\text { (\%brix) }\end{array}$ & $\begin{array}{c}\text { Volume } \\
\text { Akar }\left(\mathrm{cm}^{3}\right)\end{array}$ \\
\hline 5 & 67,81 & 658,7 & 10,56 & 2,37 & 2,82 & 7,44 & 5,75 \\
\hline 10 & 67,5 & 682,78 & 10,51 & 2,65 & 2,94 & 7,54 & 5,83 \\
\hline 15 & 66,7 & 674,07 & 10,14 & 2,57 & 2,87 & 7,07 & 5,84 \\
\hline 20 & 63,44 & 792,22 & 10,7 & 2,59 & 3,15 & 6,98 & 6,23 \\
\hline
\end{tabular}

Dosis pupuk kandang 20 ton/ha menghasilkan bobot buah, diameter buah, tebal daging dan volume akar lebih bagus dari ketiga dosis lainnya dengan umur panen yang lebih cepat. Umur panen pada dosis pupuk kandang 5 ton/ha dan 10 ton/ha paling lama mencapai rata-rata 67 hst. Pada tanaman semangka pemberian 10 ton/ha pupuk kandang mampu memberikan pertumbuhan dan hasil yang lebih baik dibandingkan kontrol (Manurung et al., 2016). Hasil penelitian Hilman \& Nurtika (1992) menunjukkan bahwa pemberian pupuk kandang 20 ton/ha dapat meningkatkan bobot buah dan jumlah buah tomat. Jika dilihat dari hasil rata-rata bobot buah melon pada dosis 20 ton/ha secara nilai ekonomi lebih menguntungkan dibandingkan dengan dosis 5 ton/ha. Pemberian dosis pupuk kandang yang semakin tinggi dapat memberikan pengaruh yang nyata terhadap tanaman selada (Evelyn et al., 2018).

Setiawan (2010) menyatakan bahwa, bahan organik memiliki peran penting di dalam tanah karena membantu menahan air, sehingga ketersediaan air lebih terjaga, meningkatkan kapasitas tukar kation atau ketersediaan hara terutama N, P dan K. Bahan organik memperbaiki aerasi tanah dan perkembangan sistem perakaran, serta memacu pertumbuhan mikroorganisme tanah yang sangat membantu proses dekomposisi bahan organik tanah.

Pada peubah volume akar terdapat perbedaan yang tidak nyata antara peningkatan dosis perlakuan pupuk kandang yang diberikan. Perakaran yang dapat menyebabkan unsur hara dan kelembaban menjadi lancar dan tanaman dapat melakukan pertumbuhan dengan baik. Rasio tajuk-akar merupakan perbandingan bobot kering tajuk dan akar tanaman. Peubah ini dapat digunakan sebagai petunjuk adanya cekaman air pada tanaman. Kekurangan air lebih menghambat pertumbuhan tajuk dibandingkan pertumbuhan akar. Pertumbuhan tajuk lebih tinggi apabila kelembaban tanah juga tinggi, pertumbuhan akar lebih tinggi apabila kelembaban tanah rendah (Gardner et al., 1991).

\section{KESIMPULAN}

Peningkatan kandungan klorofil (SPAD indeks) tertinggi di petak percobaan yang diberi pupuk kandang 20 ton/ha, sedangkan perlakuan ini tidak meningkatkan hasil melon dan komponennya. Jenis pupuk kandang hanya meningkatkan tinggi tanaman, umur panen, diameter buah, dan kandungan padatan terlarut (Brix). Aplikasi kombinasi jenis dan dosis pupuk kandang tidak meningkatkan pertumbuhan dan hasil melon.

\section{DAFTAR PUSTAKA}

Adimihardja, S.A., Sunardi, O. \& Mulyaningsih, Y. (2013). Pengaruh tingkat pemberian ZPT Gibberellin (GA3) terhadap pertumbuhan vegetatif tanaman kangkung air (Ipomea aquatica Forsk L.) pada sistem hidroponik Floating Raft Technique (FRT). Jurnal Pertanian, 4(1), 33-47. DOI: http://dx.doi.org/10.30997/jp.v4i1.546.

Andayani \& Sarido, L. (2013). Uji empat jenis pupuk kandang terhadap pertumbuhan dan hasil tanaman cabai keriting (Capsicum annum L.). Jurnal Agrifor, 12(1), 22-29.

Affandi. (2008). Pemanfaatan Urine Sapi yang Difermentasi Sebagai Nutrisi Tanaman. Universitas Sumatera Utara Press., Medan.

Azalika, R.P., Sumardi \& Sukisno. (2018). Pertumbuhan dan hasil padi Sirantau pada pemberian beberapa macam dan dosis pupuk kandang. Jurnal Ilmu-Ilmu Pertanian Indonesia, 20(1), 26-32. DOI: https://doi.org/10.31186/jipi.20.1. 26-32.

Badan Pusat Statistik. (2017). Data statistik melon Provinsi Bengkulu dan Nasional. https://www.bps. go.id_.17 April 2018.

Deus, D., Hariyono, K. \& Winarso, S. (2014). Penambahan nutrisi pada tiga varietas melon untuk meningkatkan hasil dan kualitas buah. Agritrop Jurnal Ilmu-ilmu Pertanian,12(2),147-158. DOI: http://dx.doi.org/10.32528/agr.v12i2.720. 
Evelyn, Hindarto, K.S. \& Inoriah, E. (2018). Pertumbuhan dan hasil selada (Lactuca sativa L.) dengan pemberian pupuk kandang dan abu sekam padi di Inceptisol. Jurnal Ilmu-Ilmu Pertanian Indonesia, 20(2), 46-50. DOI: https:// doi.org/10.31186/jipi.20.2.46-50.

Gardner, F.P., Pearce, R.B. \& Mitchell, R.L. (1991). Physiology of Crop Plants (Fisiologi Tanaman Budidaya. Diterjemahkan oleh Susilo, H.). Universitas Indonesia Press., Jakarta.

Hilman, Y. \& Nurtika, N. (1992). Pengaruh pupuk kandang terhadap pertumbuhan dan produksi tomat. Bulletin Penelitian Hortikultura, 22(1), 96-101.

International AG LABS. (2017). Reflactive index of crop juices, calibtated in \% sukrose or ${ }^{\circ}$ Brix. http://www.aglabs.com. 20 Agustus 2019.

Isnaini, M. (2006). Pertanian Organik. Kreasi Wacana, Yogyakarta.

Karya, B. (2009). Budidaya Tanaman Melon : Teknik Budidaya Dan Penanganan Pasca Panen. Yrama Widya, Bandung.

Laude, S., \& Tambing, Y. (2010). Pertumbuhan dan hasil bawang daun (Allium fistulosum L.) pada berbagai dosis pupuk kandang ayam. $J$. Agroland, 17(2), 144-148.

Manurung, M., Sokip, A. \& Puspitorini, P. (2016). Pengaruh pemberian dosis pupuk kandang dan jenis mulsa terhadap pertumbuhan dan produksi tanaman semangka (Citrullus vulgaris Schard) di musim hujan. VIABEL, Jurnal Ilmiah Ilmu-Ilmu Pertanian, 10, 37-52. DOI: http://10.30957/viabel.v10i1.112.

Mariana, P., Sipayung, R. \& Sinuraya. (2012). Pertumbuhan dan pengaruh produksi bawang merah (Allium ascalonicum L.) dengan pemberian vermikompos dan urine domba. Jurnal Online Agroekoteknologi,1(1), 124138.

Mardianto, R. (2014). Pertumbuhan dan hasil cabai (Capsicum annum L.) dengan pemberian pupuk organik cair daun Tithonia dan Gamal. Jurnal Gamma, 7(1), 61-68.

Mayun, I. A. (2007). Efek mulsa jerami padi dan pupuk kandang sapi terhadap pertumbuhan dan hasil bawang merah di daerah pesisir, Agritrop, 26 (1), 33-40.

Mohamed, M. A., Sekar, A. \& Muthukrishnan, P. (2010). Prospects and potential of poultry manure. Asian J. of Plant Sci.,3,641-652. DOI: http:// 10.3923/ajps.2010.172.182.

Patil, N.M. (2010). Biofertilizer effect on growth, protein and carbohydrate conten in Stevia rebaudiana var Bertoni. Recent Research Science Technology, 2(10), 42-44.
Prihmantoro, H. (2007). Memupuk Tanaman Buah. Penebar Swadaya, Jakarta.

Rizwan, M., \& Medan, S. P. F. P. U. (2010). Evaluasi pupuk NPK dan pupuk organik terhadap pertumbuhan dan produksi tanaman kacang (Arachis hypogaea L). Jurnal Ilmiah Abdi Ilmu, 3(2), 422-430.

Rosmarkam, A., \& Yuwono, N. W. (2002). Ilmu Kesuburan Tanah. Kanisius, Yogyakarta.

Safei, M., Rahmi, A. \& Jannah, N. (2014). Pengaruh jenis dan dosis pupuk organik terhadap pertumbuhan dan hasil tanaman terung (Solanum melongena L.) varietas Mustang F-1. Jurnal AGRIFOR, 13(1), 59-66. DOI: https://doi. org/10.31293/af.v13i1.549.

Safuan, L. O. \& Bahrun, A. (2012). Pengaruh bahan organik dan pupuk kalium terhadap pertumbuhan dan produksi tanaman melon (Cucumis melo L.). Jurnal Agroteknos, 2(2), 69-76.

Sari, P., Meri, R., Maghfoer, M. D., \& Koesriharti, K. (2016). Pengaruh frekuensi penyiraman dan dosis pupuk kandang ayam terhadap pertumbuhan dan hasil tanaman pakchoy (Brassica rapa $\mathrm{L}$. Var. Chinensis). Jurnal Produksi Tanaman, 4 (5), 342-351.

Sayekti, S. (2016). Pengaruh Intensitas Cahaya terhadap Kandungan Klorofil-A dan-C Zooxanthellae dari Isolat Karang Lunak Zoanthus sp. Skripsi. Fakultas Pertanian. Universitas Lampung, Lampung.

Setiawan, B. S. (2010). Membuat Pupuk Kandang Secara Cepat. Penebar Swadaya, Jakarta.

Setyawaty, R.W. (2012). Respon pertumbuhan dan produksi tanaman melon terhadap kombinasi biodegradable super absorbent polymer dengan pupuk majemuk NPK di tanah miskin hara, Jurnal Agrium, 17(3), 155-162.

Sitompul, S.M \& Guritno, B. (1995). Analisis Pertumbuhan Tanaman. Gadjah Mada University Press., Yogyakarta.

Silvia, M., Noor, G.M.S. \& Erhaka, M.E. (2012). Respon pertumbuhan dan hasil tanaman cabe rawit (Capsicum frutescent L) terhadap pemberian pupuk kandang kotoran kambing pada tanah Ultisols. Jurnal Agriculture, 19(3), 148-54.

Souri, S. (2001). Penggunaan Pupuk Kandang Meningkatkan Produksi Padi. Penebar Swasaya, Bandung.

Subhan, N. \& Setiawati, W. (2005). Peningkatan efisiensi pemupukan NPK dengan memanfaatkan bahan organik terhadap hasil tomat. Jurnal Hortikultura, 15(2), 91-96.

Subagyo, H., Suharta, N. \& Siswanto, A.B. (2004). Tanah-tanah pertanian di Indonesia. Hal 21-66. In A. Adimihardja, L.I. Amien, F. Agus, D. Djaenudin. Sumberdaya Lahan Indonesia dan 
Pengelolaannya. Pusat Penelitian dan Pengembangan Tanah dan Agroklimat, Bogor.

Sumpena, U. (2001). Budidaya Mentimun. Penebar Swadaya, Jakarta.

Sutanto, R. (2002). Penerapan Pertanian Organik: Pemasyarakatan dan Pengembangannya. Kanisius, Jakarta.
Tufaila, M. (2013). Perakitan pupuk alam berbasis sumberdaya lokal untuk meningkatkan efisiensi pemupukan $\mathrm{p}$ dan $\mathrm{k}$ serta hasil kedelai di tanah masam, J.Agroteknos, 3(3), 152-162. 